\title{
Studi Perbandingan Efisiensi Perbaikan Mutu Air Limbah Domestik melalui Filtrasi Horizontal dengan Beton Porous Recycled Aggregate Berlapis
}

\author{
Ariza J. Hakim ${ }^{1 *}$, Evi Nur Cahya ${ }^{1}$, Riyanto Haribowo ${ }^{1}$ \\ ${ }^{1}$ Jurusan Teknik Pengairan, Fakultas Teknik, Universitas Brawijaya, \\ Jalan MT. Haryono No. 167, Malang, 65145, INDONESIA
}

*Korespondensi Email: arzanhakim@ @student.ub.ac.id

\begin{abstract}
Domestic wastewater pollution is one of the reasons for the decline in the national Water Quality Index. The increasing number of people with inadequate sanitation facilities requires a solution. Porous concrete with RCA aggregate has the potential to improve domestic wastewater. Made of porous concrete, the filter is made with dimensions of $40 \times 40 \times 5 \mathrm{~cm}^{3}$ using RCA aggregate with $0.5-2.0 \mathrm{~cm}$ gradation. Two reactor models of the same size were prepared, containing 3 and 4 layers of filters. Domestic wastewater as a test object comes from Tlogomas Integrated Sewer System, flowed continuously into the model. The results of Test 1 show that the 3-Filters Reactor Model can improve the $\mathrm{pH}$ and COD values according to the quality standard, while the 4-Filters Reactor Model can only improve the $\mathrm{pH}$ value. The results of Test 2 show that the 3-Filters Reactor Model can improve the $\mathrm{pH}$ and TSS values according to the quality standard, while the 4-Filters Reactor Model can only improve the $\mathrm{pH}$ value. The average efficiency of the filtration against influent shows that the 3Filters Reactor Model is better than the 4-Filters Reactor Model with the percentage of improvement in $\mathrm{pH} 11.54 \%$, BOD $26.15 \%$, COD $20.79 \%$, and TSS $46.37 \%$..
\end{abstract}

Keywords: Domestic wastewater, Porous concrete, Recycled Coarse Aggregate, Wastewater treatment

Abstrak: Pencemaran air limbah domestik menjadi salah satu sebab penurunan Indeks Kualitas Air nasional. Peningkatan jumlah penduduk dengan fasilitas sanitasi yang kurang layak menjadikan diperlukannya solusi. Beton porous dengan agregat RCA memiliki potensi untuk memperbaiki air buangan rumahan. Terbuat dari beton porous, filter dibuat dengan dimensi $40 \times 40 \times 5 \mathrm{~cm}^{3}$ menggunakan agregat RCA bergradasi butiran $0,5-2,0 \mathrm{~cm}$. Dua model reaktor berukuran sama disiapkan, berisi 3 
dan 4 lapis filter. Air limbah domestik sebagai benda uji berasal dari MCK Terpadu Tlogomas, dialirkan secara menerus ke dalam model. Hasil Uji 1 menunjukkan Model Reaktor 3 Filter mampu memperbaiki nilai $\mathrm{pH}$ dan COD sesuai baku mutu, sedangkan Model Reaktor 4 Filter hanya dapat memperbaiki nilai pH. Hasil Uji 2 menunjukkan Model Reaktor 3 Filter mampu memperbaiki nilai $\mathrm{pH}$ dan TSS sesuai baku mutu, sedangkan Model Reaktor 4 Filter hanya dapat memperbaiki nilai pH. Efisiensi rerata filtrasi terhadap influen menunjukkan bahwa Model Reaktor 3 Filter lebih baik daripada Model Reaktor 4 Filter dengan persentase perbaikan $\mathrm{pH}$ $11,54 \%$, BOD 26,15\%, COD 20,79\%, dan TSS 46,37\%.

Kata kunci: Air limbah domestik, Beton porous, Pengolahan air limbah, Recycled Coarse Aggregate

\section{Pendahuluan}

Laporan Direktorat Pengendalian Pencemaran Air tahun 2019 menyebutkan bahwa Indeks Kualitas Air nasional tahun 2018 mengalami penurunan sebanyak 2,19 poin [1]. Bertambahnya beban pencemaran berupa air limbah domestik menjadi salah satu penyebabnya. Jumlah penduduk yang semakin meningkat dengan fasilitas sanitasi yang kurang layak memberikan peranan. Ditambah dengan keterbatasan lahan yang semakin menyempit akibat kebutuhan pemukiman bertambah, membuat perlunya solusi yang inovatif.

Memanfaatkan sifat beton porous yang mampu menyerap air dan menyaringnya, digunakanlah beton porous sebagai media filter. Beton tersebut dibuat dengan komposisi agregat daur ulang (recycled coarse aggregate, RCA) dengan gradasi butiran berdiameter 0,5-2,0 mm. Penggunaan RCA menunjukkan performa penyaringan polutan air yang lebih baik dibanding dengan beton porous dengan agregat normal [2]. Gradasi butiran dengan ukuran tersebut memiliki efisiensi filtrasi yang paling tinggi dalam menurunkan nilai TSS, BOD, dan COD [3]. Filter beton porous tersebut disusun ke dalam suatu model reaktor. Ada dua model reaktor yang dibuat, satu berisi 3 lapis filter dan satu lainnya berisi 4 lapis. Kedua model reaktor tersebut menggunakan sistem filtrasi horizontal. Sistem ini dipilih karena memiliki keuntungan seperti: mudah dibuat, mudah dioperasikan dan dipelihara, berbiaya efektif, dan dapat diandalkan [4]. Sistem operasinya menggunakan aliran menerus (continuous flow) yang dioperasikan mulai pagi hingga sore.

Tujuan yang ingin digapai dari penelitian ini adalah untuk mengetahui perbandingan efisiensi filtrasi yang dilakukan oleh kedua model reaktor dalam menyaring air limbah domestik.

\section{Bahan dan Metode}

2.1 Bahan

\subsubsection{Influen}

Air limbah yang digunakan sebagai influen berasal dari Kolam Inlet yang terdapat di MCK 
Terpadu Tlogomas. Air limbah ini merupakan air buangan dari pemukiman yang menampung sebanyak 112 Kepala Keluarga [3]. Air buangan ini terdiri dari blackwater dan greywater.

\subsubsection{Filter}

Penelitian ini menggunakan filter berukuran $40 \times 40 \times 5 \mathrm{~cm}^{3}$ sebagai media filtrasi. Ketebalan $5 \mathrm{~cm}$ dipilih agar kecepatan air yang melewati filter akan optimal [5]. Filter yang digunakan berasal dari beton porous yang dibuat dengan komposisi dasar agregat RCA bergradasi butiran 0,5-2,0 cm. Agregat ini dicampurkan dengan semen portland dan air PDAM. Beton porous dicetak dengan bekesting yang dilapisi plastik supaya tidak terkontaminasi dan mudah untuk diangkat. Setelah beton dicetak, akan dilakukan curing selama 7 hari [6].

\subsubsection{Model reaktor}

Model reaktor dibuat dengan material berupa kaca akrilik untuk memudahkan pengamatan. Model reaktor yang dibuat memiliki dimensi berukuran $100 \times 41 \times 40 \mathrm{~cm} 3$. Dasar model reaktor memiliki kemiringan sebesar 5\% dengan hilir yang paling rendah. Pada dinding hilir, terdapat lubang outlet berdiameter $2,5 \mathrm{~cm}$ dengan dasar lubang setinggi $30 \mathrm{~cm}$ dari dasar model reaktor. Detail desain model reaktor dapat dilihat pada Gambar 1.

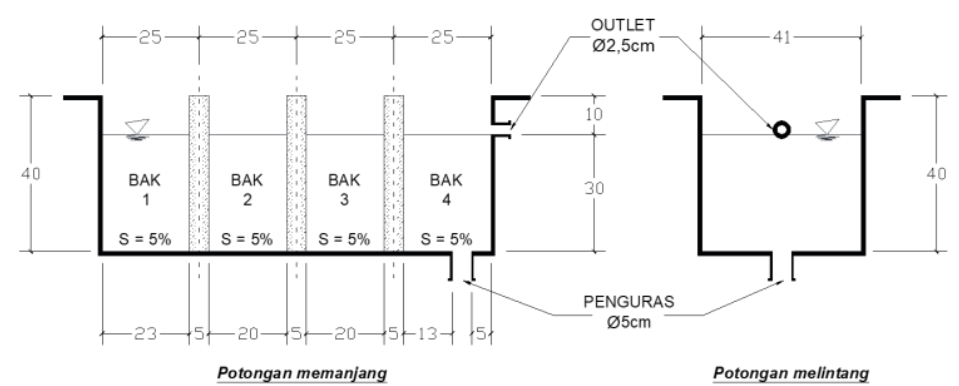

Model reaktor 3 filter

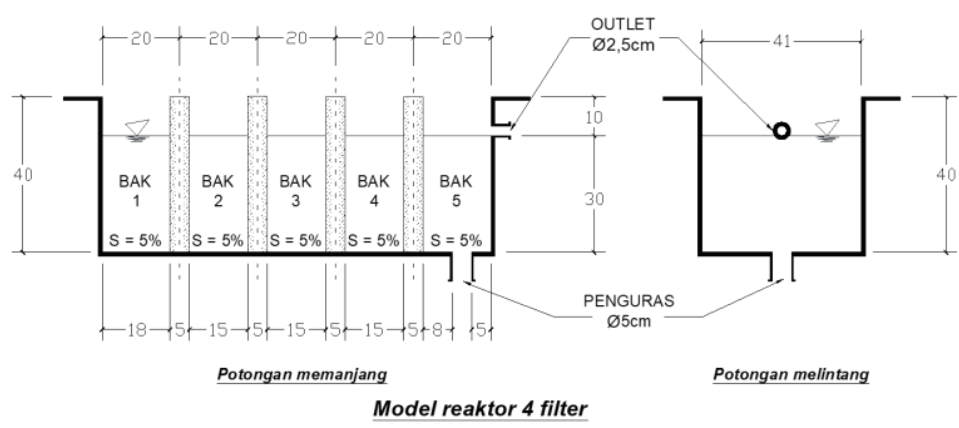

Gambar 1: Desain model reaktor.

Diketahui Model Reaktor 3 Filter memiliki volume netto sebesar $104.550 \mathrm{~cm}^{3}$. Sedangkan Model Reaktor 4 Filter memiliki volume netto sebesar $98.400 \mathrm{~cm}^{3}$

\subsection{Metode}

\subsubsection{Debit rencana dan waktu retensi}

Dalam menghitung debit rencana air limbah domestik, digunakan beberapa persamaan 
yang sama dengan perhitungan kebutuhan air bersih. Ini disebabkan karena 50-80\% air bersih menjadi air buangan [3], sedangkan sisanya adalah yang terpakai untuk berbagai keperluan dan yang menguap dari tempat penampungannya [7].

Perhitungan debit rencana air limbah dapat dilakukan dengan Persamaan 1 berikut:

$$
Q_{\text {rerata }}=Q_{a b} \times \text { Jumlah orang } \times f a b \quad \text { Pers. } 1
$$

dengan:

$Q_{\text {rerata }}=$ debit harian rerata $(\mathrm{L} / \mathrm{hr})$

$Q_{a b} \quad=$ kebutuhan air bersih $(\mathrm{L} / \mathrm{org} / \mathrm{hr})$

fab = faktor air buangan $(0,5$ sampai 0,8$)$

Kebutuhan air bersih dapat ditentukan berdasarkan kategori suatu daerah seperti yang ditunjukkan pada Tabel 1 [8]. Jumlah pemakai air bersih ditetapkan 5 orang per rumah [9].

Kota Malang pada tahun 2018 memiliki jumlah penduduk sebanyak 866.118 orang [10]. Berdasarkan Tabel 1, Kota Malang termasuk ke dalam kategori sebagai Kota Besar. Diasumsikan kebutuhan air bersih $\left(Q_{a b}\right)$ sebesar $150 \mathrm{~L} / \mathrm{org} / \mathrm{hr}$, jumlah orang per rumah sebanyak 5 orang, dan Faktor air buangan $(f a b)$ sebesar $0,7$.

Tabel 1: Kebutuhan air bersih domestik

\begin{tabular}{lcc}
\hline \multicolumn{1}{c}{ Kategori Kota } & $\begin{array}{c}\text { Jumlah Penduduk } \\
\text { (org) }\end{array}$ & $\begin{array}{c}\text { Kebutuhan Air Bersih } \\
\text { (L/org/hr) }\end{array}$ \\
\hline \hline Kecamatan/desa & $3.000-20.000$ & $60-90$ \\
Kota kecil & $20.000-100.000$ & $90-110$ \\
Kota sedang & $100.000-500.000$ & $100-125$ \\
Kota besar & $500.000-1.000 .000$ & $120-150$ \\
Kota metropolitan & $>1.000 .000$ & $150-200$ \\
\hline
\end{tabular}

Dengan Persamaan 1, maka debit rerata harian dapat dicari sebagai berikut:

$$
\begin{aligned}
Q_{\text {rerata }} & =Q_{a b} \times \text { Jumlah orang } \times \text { fab } \\
& =150 \mathrm{~L} / \mathrm{org} / \mathrm{hr} \times 5 \text { org } \times 0,7 \\
& =525 \mathrm{~L} / \mathrm{hr} \\
& =0,3646 \mathrm{~L} / \mathrm{mnt}
\end{aligned}
$$

Dapat dicari debit air limbah domestik harian maksimum dengan Persamaan 2 berikut:

$$
Q_{\text {hmaks }}=f m \times Q_{\text {rerata }} \quad \text { Pers. } 2
$$

dengan:

$Q_{\text {hmaks }}=$ debit harian maksimum (L/mnt)

$\mathrm{fm} \quad=$ faktor hari maksimum $(1,15$ sampai 1,25$)$

$Q_{\text {rerata }}=$ debit harian rerata $(\mathrm{L} / \mathrm{hari})$

Dengan nilai faktor hari maksimum ( $f m$ ) sebesar 1,2; maka didapatkan:

$$
\begin{aligned}
Q_{\text {hmaks }} & =f m \times Q_{\text {rerata }} \\
& =1,2 \times 0,3646 \mathrm{~L} / \mathrm{mnt} \\
& =0,4375 \mathrm{~L} / \mathrm{mnt}
\end{aligned}
$$


Lalu, dihitung jam puncak (peak hour) pembuangan air limbah domestik yang dilakukan oleh penduduk. Jam puncak ini merupakan waktu dimana terjadi pembuangan air limbah tertinggi pada satu hari sesuai dengan aktivitas yang dilakukan oleh masyarakat. Jam puncak umumnya terjadi sekitar pukul 05.00-10.00 dan 17.00-20.00 [11]. Debit pada jam puncak digunakan sebagai debit rencana air limbah domestik. Perhitungannya dapat dilakukan dengan Persamaan 3 berikut:

$$
Q_{p}=f p \times Q_{\text {hmaks }} \quad \text { Pers. } 3
$$

dengan:

$Q_{p} \quad=$ debit harian pada jam puncak $(\mathrm{L} / \mathrm{hr})$

$\mathrm{fp} \quad=$ faktor jam puncak $(1,75$ sampai 2,0$)$

$Q_{\text {hmaks }}=$ debit harian maksimum $(\mathrm{L} / \mathrm{hr})$

Dengan nilai faktor jam puncak $(f p)$ sebesar 2,0; maka didapatkan:

$$
\begin{aligned}
Q_{p} & =f p \times Q_{\text {hmaks }} \\
& =2,0 \times 0,4375 \mathrm{~L} / \mathrm{mnt} \\
& =0,8750 \mathrm{~L} / \mathrm{mnt}
\end{aligned}
$$

Dengan demikian, debit rencana untuk model reaktor adalah sebesar 0,875 L/mnt

Waktu retensi atau waktu tinggal adalah waktu yang dibutuhkan air limbah mengalir dimulai dari masuknya melalui inlet model reaktor hingga keluar dari outlet. Untuk mencari lama waktu tinggal, dapat dicari dengan Persamaan 4 berikut:

$$
T=\frac{V}{Q} \quad \text { Pers. } 4
$$

dengan:

$T$ = waktu tinggal (mnt)

$V=$ volume bak penampung $\left(\mathrm{cm}^{3}\right)$

$Q=$ debit rencana $=$ debit pada jam puncak $\left(\mathrm{cm}^{3} / \mathrm{mnt}\right)$

Maka, waktu retensi untuk Model Reaktor 3 Filter adalah:

$$
\begin{aligned}
T M R 3 F & =V M R 3 F / Q_{\text {rencana }} \\
& =104.550 / 875 \\
& =119,49 \mathrm{mnt} \approx 2 \mathrm{jam}
\end{aligned}
$$

Sedangkan waktu retensi untuk Model Reaktor 4 Filter adalah:

$$
\begin{aligned}
T M R 4 F & =V M R 4 F / Q_{\text {rencana }} \\
& =98.400 / 875 \\
& =112,46 \mathrm{mnt} \approx 2 \mathrm{jam}
\end{aligned}
$$

\subsubsection{Operasi model reaktor}

Model reaktor dijalankan selama 10 hari secara kontinyu (continuous flow). Pengoperasian dilakukan mulai pukul 07.00 hingga 17.00. Jam pengoperasian dilakukan dengan mempertimbangkan jam puncak pemakaian air yang terjadi pada pukul 07.00-08.00 
dan pukul 16.00-17.00. Pada jam puncak pemakaian air, akan terjadi pula jam puncak pembuangan air limbah.

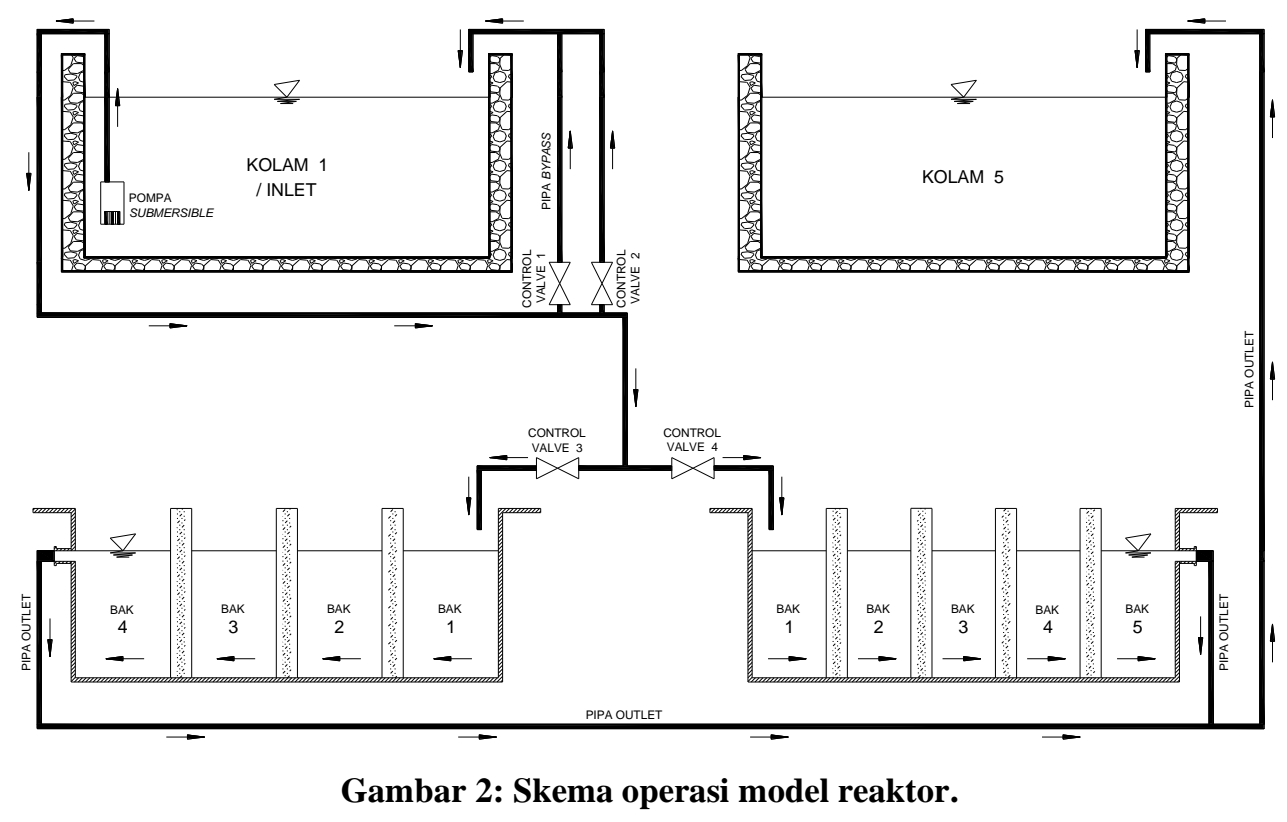

Penelitian ini menggunakan sebuah pompa untuk mengaliri influen menuju ke kedua model reaktor. Pompa yang digunakan untuk mengalirkan air limbah menuju ke model reaktor adalah pompa celup. Setelah digerakkan pompa, aliran kemudian menuju Keran Pengatur 1. Sebelum keran ini, terdapat saluran bypass yang menuju ke Kolam 1. Saluran ini untuk mengalirkan kelebihan debit pada Keran Pengatur 1.

Setelah melalui Keran Pengatur 1, selanjutnya aliran akan melalui Keran Pengatur 2. Keran ini untuk mengatur besar debit agar lebih kecil jika debit di Keran Pengatur 1 tidak memungkinkan untuk dikecilkan lagi. Setelah melewati Keran Pengatur 2, maka aliran akan dibagi melalui tee, masing-masing menuju ke model reaktor. Aliran yang telah melewati model selanjutnya akan mengalir melalui pipa outlet menuju ke Kolam 5. Pipa outlet terpasang pada suatu lubang pelimpah dengan ketinggian $30 \mathrm{~cm}$ dari dasar model.

\subsubsection{Pengambilan sampel}

Pengambilan sampel dilakukan dengan cara mengambil sampel dengan menggunakan alat berupa gayung. Titik sampel yang diambil adalah sebagai berikut:
a. kolam inlet di dekat pompa,
b. setiap bak pada model reaktor 3 filter yang berjumlah 4 titik, dan
c. setiap bak pada model reaktor 4 filter yang berjumlah 5 titik.

Sampel-sampel ini kemudian dimasukkan ke dalam botol sampel yang terbuat dari plastik polyethylene (PE). Botol ini sebelumnya telah diberi kode sesuai dengan sampel yang ingin dimasukkan. Botol yang telah berisi sampel lalu disimpan di dalam kotak pendingin. Setiap parameter memiliki cara pengawetan dan penyimpanan dengan durasi masing-masing. Ini dimaksudkan supaya sampel yang diambil dan disimpan masih layak untuk diuji sehingga akan menghasilkan nilai yang kredibel [12].

\subsubsection{Pengujian sampel}


Setiap sampel memiliki parameter yang akan dianalisis. Analisis dilakukan di lokasi penelitian dan di Laboratorium milik Perum Jasa Tirta 1 (PJT-1). Parameter tersebut antara lain:
a. $\mathrm{pH}$,
b. BOD (Biological Oxygen Demand),
c. COD (Chemical Oxygen Demand), dan
d. TSS (Total Suspended Solid).

\subsubsection{Baku mutu air limbah domestik}

Baku mutu air limbah merupakan ukuran batas kadar atau jumlah unsur pencemar yang berada dalam air limbah yang akan dibuang atau dilepas ke dalam suatu sumber/media air dari suatu usaha dan/atau kegiatan [13]. Baku mutu air limbah menjadi penentu apakah air limbah tersebut telah aman untuk dilepas ke alam, terutama sumber air. Menurut Peraturan Menteri LHK, baku mutu untuk air limbah domestik adalah sebagai berikut [14].

Tabel 2: Baku mutu air limbah domestik Permenlhk No. 68 Th. 2016

\begin{tabular}{|c|c|c|c|}
\hline No. & Parameter & Satuan & Kadar Maksimum \\
\hline 1. & $\mathrm{pH}$ & - & $6-9$ \\
\hline 2. & BOD & $\mathrm{mg} / \mathrm{L}$ & 30 \\
\hline 3. & COD & $\mathrm{mg} / \mathrm{L}$ & 100 \\
\hline 4. & TSS & $\mathrm{mg} / \mathrm{L}$ & 30 \\
\hline 5. & Minyak dan lemak & $\mathrm{mg} / \mathrm{L}$ & 5 \\
\hline 6. & Amoniak & $\mathrm{mg} / \mathrm{L}$ & 30 \\
\hline 7. & Total Coliform & jumlah/100mL & 3000 \\
\hline 8. & Debit & L/orang/hari & 100 \\
\hline
\end{tabular}

Kadar maksimum yang ditunjukkan pada Tabel 2 di atas berlaku untuk: rumah susun, penginapan, asrama, pelayanan kesehatan, lembaga pendidikan, perkantoran, perniagaan, pasar, rumah makan, balai pertemuan, area rekreasi, pemukiman, industri, IPAL kawasan, IPAL pemukiman, IPAL perkotaan, pelabuhan, bandara, stasiun kereta api, terminal, dan lembaga pemasyarakatan.

Peraturan Gubernur Jawa Timur memberikan baku mutu berikut [15].

Tabel 3: Baku mutu air limbah domestik Pergub Jatim No. 72 Th. 2013

\begin{tabular}{clcc}
\hline No. & \multicolumn{1}{c}{ Parameter } & Satuan & Kadar Maksimum \\
\hline 1. & BOD5 & - & 30 \\
2. & COD & $\mathrm{mg} / \mathrm{L}$ & 50 \\
3. & TSS & $\mathrm{mg} / \mathrm{L}$ & 50 \\
4. & Minyak dan lemak & $\mathrm{mg} / \mathrm{L}$ & 10 \\
5. & $\mathrm{pH}$ & $\mathrm{mg} / \mathrm{L}$ & $6-9$ \\
\hline
\end{tabular}

Baku mutu air limbah domestik sesuai dengan Pergub Jatim pada Tabel 3 di atas ditujukan untuk pemukiman (real estate), rumah makan (restoran), perkantoran, perniagaan, apartemen, perhotelan, dan asrama.

\subsubsection{Efisiensi}


Dalam perbandingan hasil pengolahan air limbah, suatu instalasi pengolahan air limbah memiliki efisiensi yang lebih baik apabila efluennya memiliki nilai yang lebih rendah daripada influen pada parameter yang sama. Untuk menentukan tingkat efisiensi dari filtrasi yang dilakukan oleh beton porous di dalam suatu model reaktor, digunakan Persamaan 5 sebagai berikut [16]:

$$
E r=\frac{\left(\Sigma C_{0} / n\right)-\left(\Sigma C_{e} / n\right)}{\left(\Sigma C_{0} / n\right)} \quad \text { Pers. } 5
$$

$$
\begin{array}{ll}
\text { dengan: } & \\
E r & =\text { efisiensi rerata }(\%) \\
\Sigma & =\text { jumlah } \\
C_{0} & =\text { konsentrasi influen } \\
C_{e} & =\text { konsentrasi efluen } \\
n & =\text { banyaknya perhitungan efisiensi }
\end{array}
$$

\section{Hasil dan Pembahasan}

3.1 Hasil pengujian kualitas air

\subsubsection{Pengujian 1}

Terdapat dua pengujian pada penelitian ini. Pengujian pertama dilakukan pada hari pertama pengoperasian model reaktor. Pengambilan sampel dilakukan setelah waktu retensi tercapai. Hasil pengujian tiap parameter disajikan ke dalam beberapa grafik berikut.

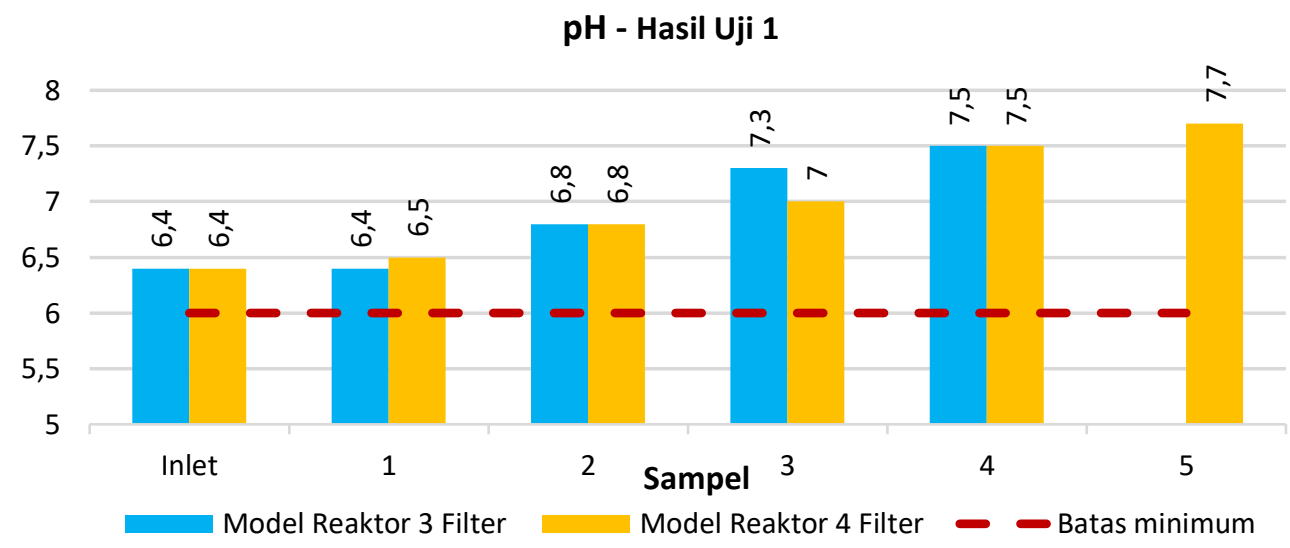

Gambar 3: Grafik perbandingan nilai pH Model Reaktor 3 dan 4 Filter pada Uji 1.

Dari Gambar 3, dapat dilihat bahwa nilai $\mathrm{pH}$ dari sampel kedua model reaktor mengalami kenaikan secara berangsur-angsur dari sampel inlet hingga sampel bak akhir. Nilai akhir sampel Model Reaktor 3 Filter pada Bak $4(7,5)$ sama dengan nilai sampel Bak 4 pada Model Reaktor 4 Filter (7,5). Sedangkan nilai sampel akhir pada Bak 5 Model Reaktor 4 Filter adalah 7,7. Baik sampel pada Model Reaktor 3 maupun 4 Filter, keduanya sama-sama telah memenuhi standar baku mutu yang ditetapkan di Peraturan Menteri LHK dan Peraturan Gubernur Jatim tersebut. 
BOD - Hasil Uji 1

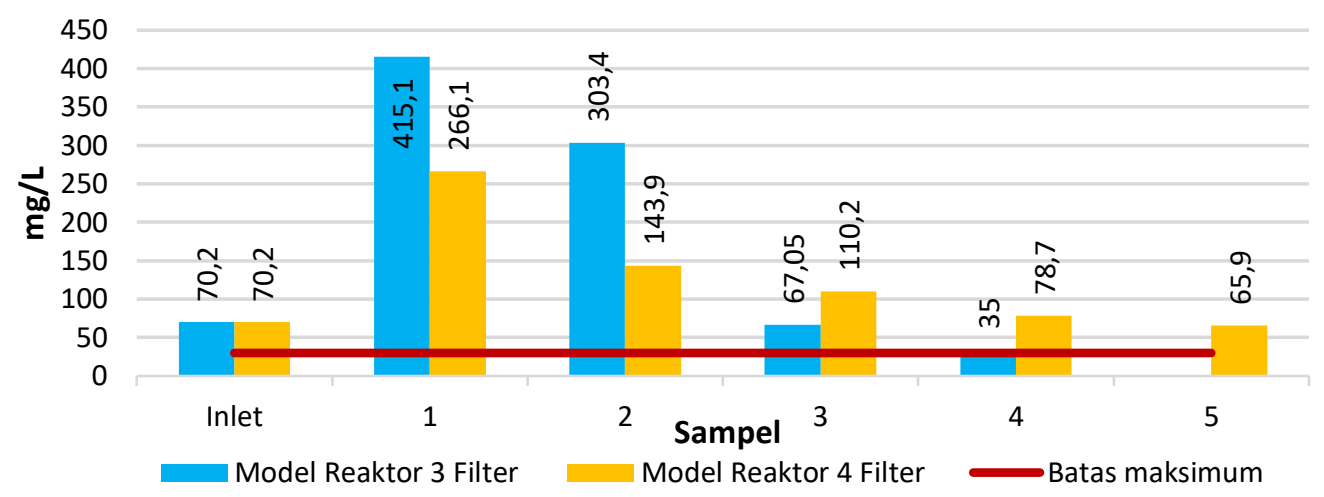

Gambar 4: Grafik perbandingan nilai BOD Model Reaktor 3 dan 4 Filter pada Uji 1.

Hasil pengujian BOD dapat dilihat pada Gambar 4. Terjadi kenaikan yang signifikan pada sampel Bak 1 kedua model reaktor dibandingkan dengan nilai BOD sampel inlet. Sampel Bak 1 Model Reaktor 3 Filter $(415,1 \mathrm{mg} / \mathrm{L})$ memiliki nilai yang lebih tinggi daripada sampel Bak 1 Model Reaktor 4 Filter (303,2 mg/L). Nilai BOD pada kedua Model reaktor sama-sama menurun setelah sampel Bak 2. Nilai akhir BOD Model Reaktor 3 Filter pada sampel Bak 4 sebesar $35 \mathrm{mg} / \mathrm{L}$, sedangkan pada sampel Bak 5 Model Reaktor 4 Filter adalah $65,9 \mathrm{mg} / \mathrm{L}$. Keduanya sama-sama belum memenuhi standar baku mutu yang ditetapkan di Peraturan Menteri LHK dan Peraturan Gubernur Jatim tersebut.

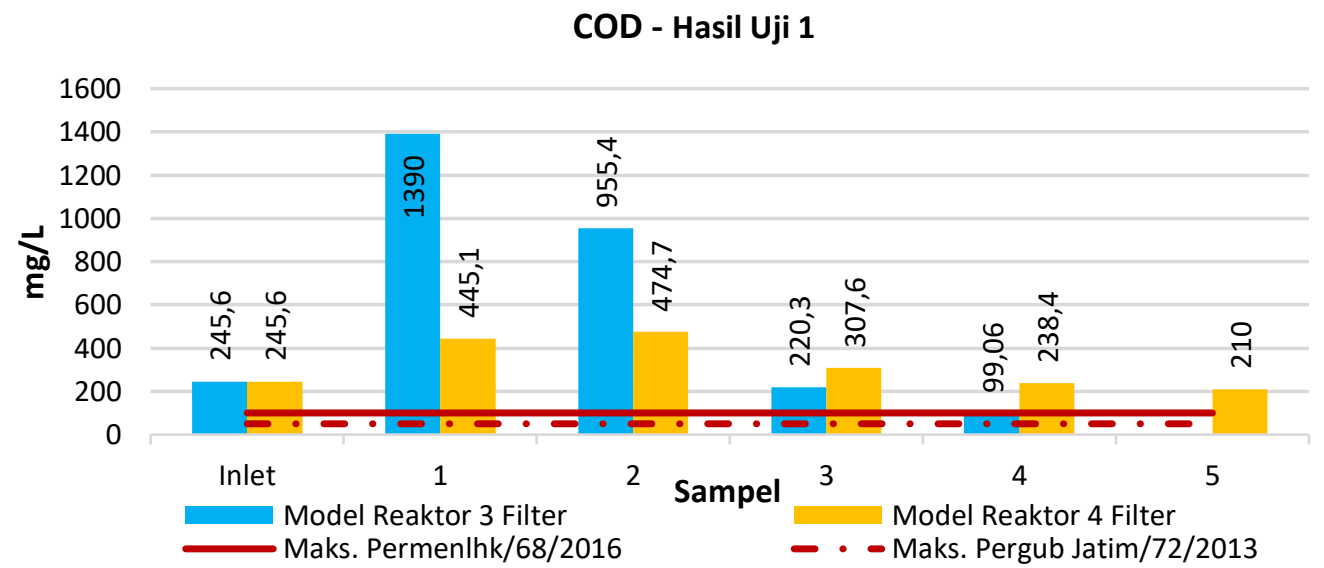

Gambar 5: Grafik perbandingan nilai COD Model Reaktor 3 dan 4 Filter pada Uji 1.

Hasil pengujian COD dapat dilihat pada Gambar 5. Diketahui bahwa kenaikan nilai COD sampel Bak 1 pada Model Reaktor 3 Filter $(1.390 \mathrm{mg} / \mathrm{L})$ lebih signifikan daripada sampel Bak 1 pada Model Reaktor 4 Filter (445,1 mg/L). Pada sampel Bak 2, Model Reaktor 3 Filter lebih rendah $(955,4 \mathrm{mg} / \mathrm{L})$ daripada sampel Bak 1. Sedangkan nilai COD pada Model Reaktor 4 Filter lebih tinggi (474,7 mg/L) daripada sampel Bak 1-nya. Sampel Bak 3 dan seterusnya pada kedua model reaktor berangsur-angsur menurun. Nilai COD pada sampel akhir Bak 4 Model Reaktor 3 Filter adalah 99,06 mg/L. Sedangkan pada Model Reaktor 4 Filter, nilai COD-nya sebesar $210 \mathrm{mg} / \mathrm{L}$. Sampel akhir Model Reaktor 3 Filter telah memenuhi baku mutu pada Peraturan Menteri LHK, namun belum memenuhi 
Peraturan Gubernur Jatim. Sedangkan sampel akhir Model Reaktor 4 Filter belum memenuhi baku mutu kedua peraturan tersebut.

TSS - Hasil Uji 1

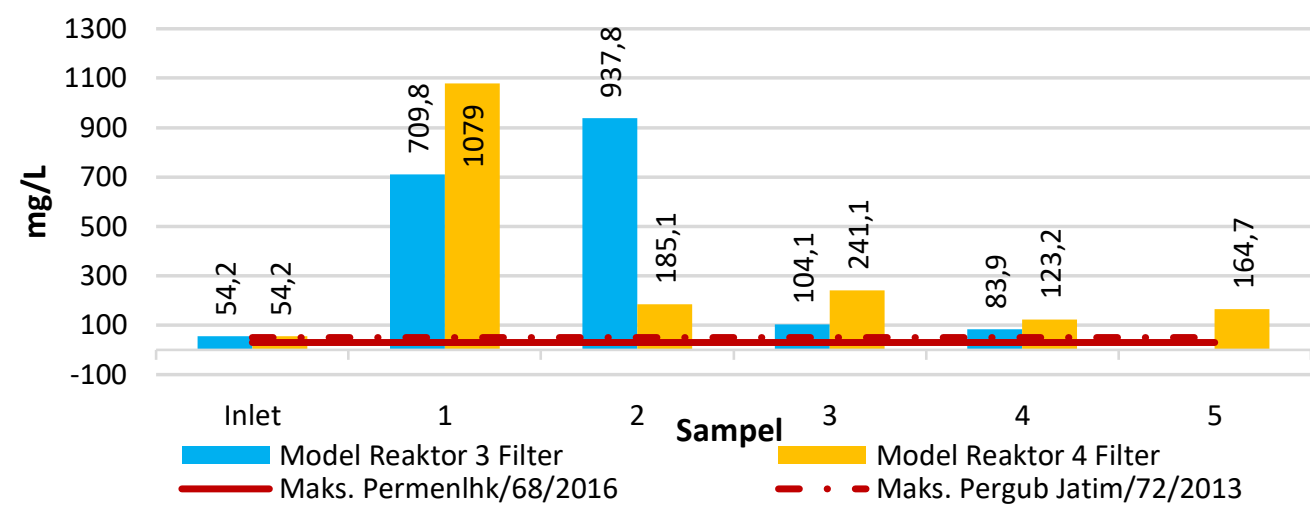

Gambar 6: Grafik perbandingan nilai TSS Model Reaktor 3 dan 4 Filter pada Uji 1.

Hasil pengujian TSS dapat diketahui dari Gambar 6, terjadi kenaikan yang drastis nilai TSS pada sampel Bak 1 kedua model dibandingkan dengan sampel inlet $(54,2 \mathrm{mg} / \mathrm{L})$. Sampel Bak 1 Model Reaktor 3 Filter memiliki nilai sebesar 709,8 mg/L, sedangkan sampel Bak 1 Model Reaktor 4 Filter sebesar $1.079 \mathrm{mg} / \mathrm{L}$. Pada sampel Bak 2 Model Reaktor 3 Filter, terjadi kenaikan menjadi 937,8 mg/L. Sedangkan pada sampel Bak 2 Model Reaktor 4 Filter, terjadi penurunan yang signifikan menjadi $185,1 \mathrm{mg} / \mathrm{L}$. Nilai sampel akhir TSS pada sampel Bak 4 Model Reaktor 3 Filter adalah $83,9 \mathrm{mg} / \mathrm{L}$. Sedangkan pada sampel Bak 5 Model Reaktor 4 Filter sebesar 164,7 mg/L. Keduanya masih di atas baku mutu yang ditetapkan pada kedua peraturan sehingga belum memenuhi standar.

\subsubsection{Pengujian 2}

Pengujian kedua dilakukan pada hari ke-10 sejak model reaktor dioperasikan untuk pertama kali. Pengambilan sampel dilakukan setelah waktu retensi tercapai. Hasil pengujian kedua pada tiap parameter disajikan ke dalam beberapa grafik berikut.

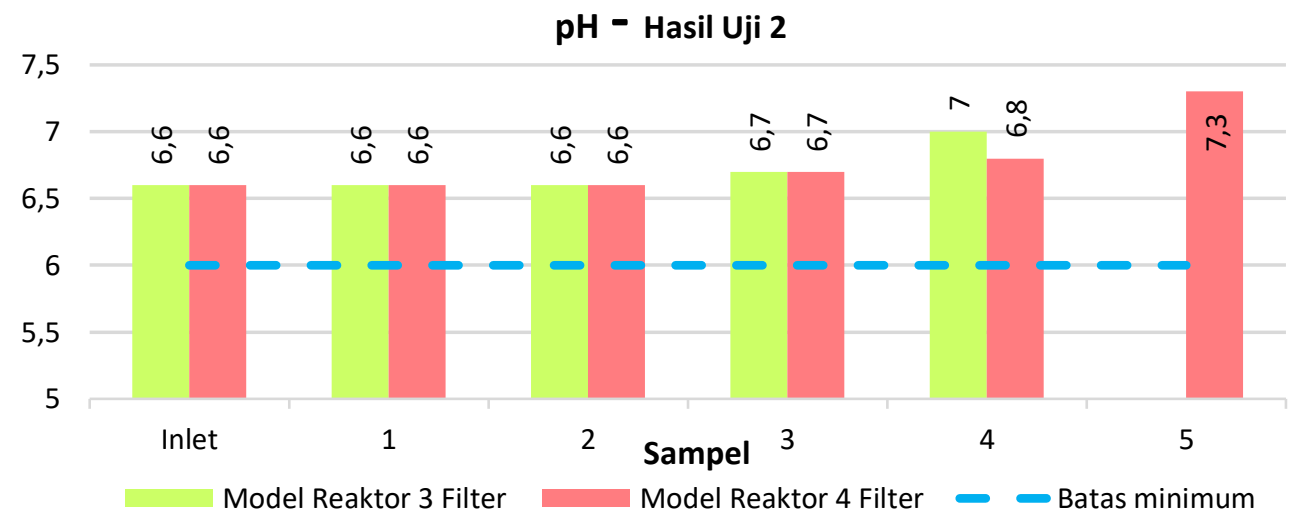

Gambar 7: Grafik perbandingan nilai pH Model Reaktor 3 dan 4 Filter pada Uji 2. 
Dari Gambar 7, dapat dilihat bahwa nilai pH dari sampel inlet dan kedua Model reaktor relatif sama hingga pada Bak 2, kemudian mengalami kenaikan secara berangsur-angsur. Nilai COD akhir sampel Model Reaktor 3 Filter pada Bak 4-nya adalah 7,0. Sedangkan nilai sampel akhir pada Bak 5 Model Reaktor 4 Filter adalah 7,3. Baik sampel pada Model Reaktor 3 maupun 4 filter, keduanya sama-sama telah memenuhi standar baku mutu yang ditetapkan di Peraturan Menteri LHK dan Peraturan Gubernur Jatim tersebut.

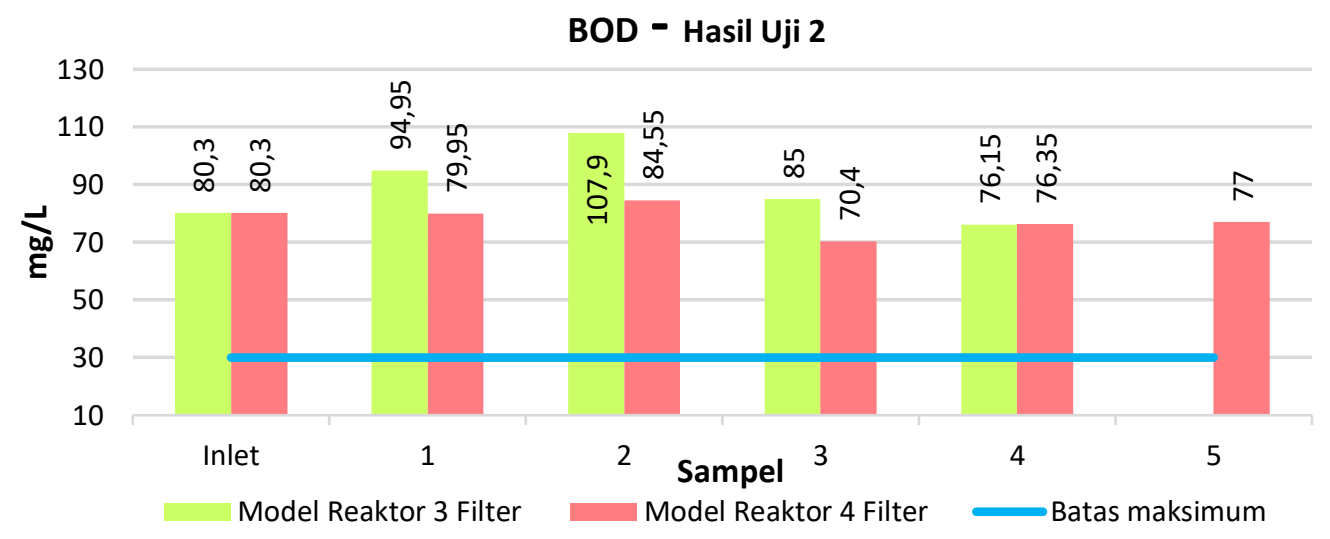

Gambar 8: Grafik perbandingan nilai BOD Model Reaktor 3 dan 4 Filter pada Uji 2.

Hasil pengujian BOD terlihat pada Gambar 8. Nilai BOD mengalami kenaikan dari sampel inlet $(80,3 \mathrm{mg} / \mathrm{L})$ hingga sampel Bak $2(107,9 \mathrm{mg} / \mathrm{L})$ Model Reaktor 3 Filter. Kemudian nilai BOD menurun hingga sampai pada sampel akhir Bak 4 yang menjadi 76,15 mg/L. Sedangkan pada Model Reaktor 4 Filter, terlihat bahwa nilai COD mengalami fluktuasi yang cenderung datar. Nilai akhir pada sampel Bak 5 adalah sebesar $77 \mathrm{mg} / \mathrm{L}$. Kedua nilai sampel akhir sama-sama masih berada di atas baku mutu yang ditetapkan di Peraturan Menteri LHK dan Peraturan Gubernur Jatim sehingga belum memenuhi standar.

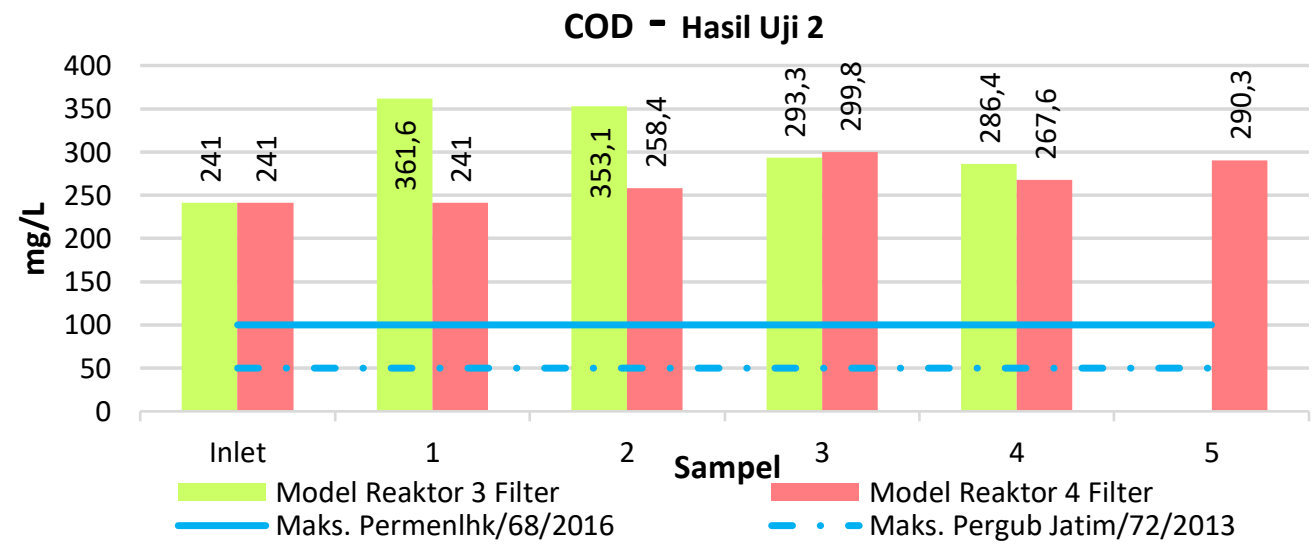

Gambar 9: Grafik perbandingan nilai COD Model Reaktor 3 dan 4 Filter pada Uji 2.

Hasil pengujian COD dapat diamati pada Gambar 9. Diketahui bahwa nilai COD sampel Bak 1 (361,6 mg/L) Model Reaktor 3 Filter memiliki nilai COD yang lebih tinggi daripada sampel inlet $(241 \mathrm{mg} / \mathrm{L})$. Nilai COD kemudian secara bertahap menurun. Sampel 
akhir di Bak 4 menunjukkan nilai COD berada pada angka 286,4 mg/L. Sedangkan nilai COD pada sampel Bak 1 Model Reaktor 4 Filter sama dengan sampel inlet $(241 \mathrm{mg} / \mathrm{L})$. Nilai COD mulai mengalami fluktuasi pada sampel Bak $2(258,4 \mathrm{mg} / \mathrm{L})$ hingga sampel Bak 5 (290,3 mg/L), dengan nilai tertinggi terjadi di sampel Bak 3 (299,8 mg/L). Sampel akhir pada kedua model sama-sama masih berada di atas baku mutu yang ditetapkan di Peraturan Menteri LHK dan Peraturan Gubernur Jatim sehingga belum memenuhi standar.

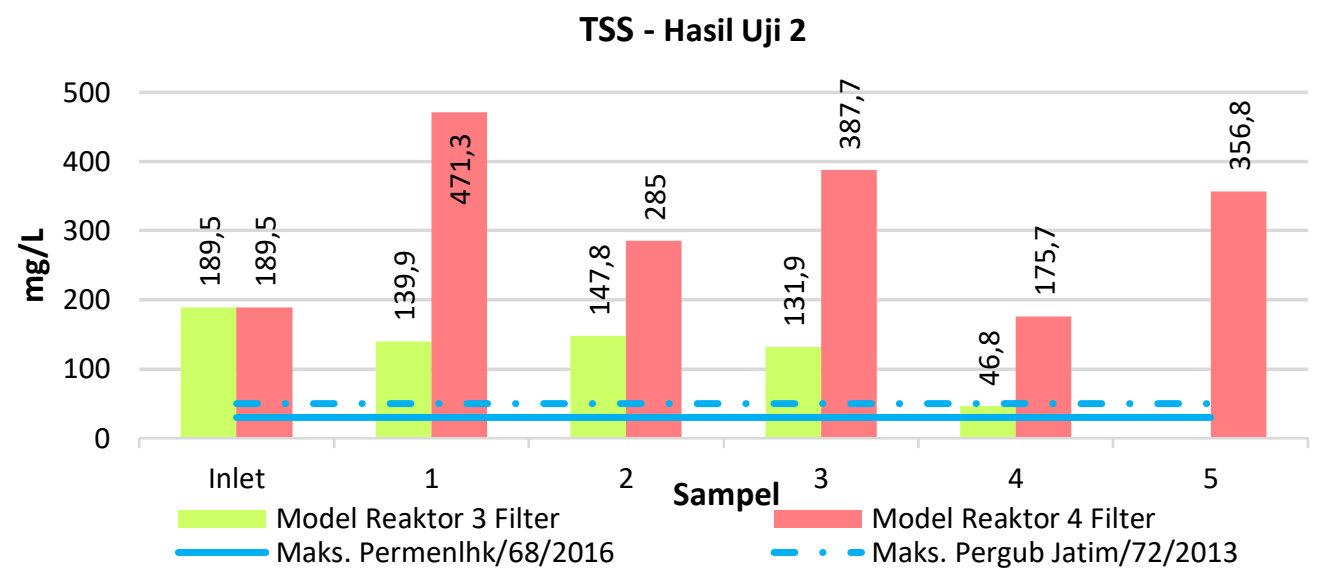

Gambar 10: Grafik perbandingan nilai TSS Model Reaktor 3 dan 4 Filter pada Uji 2.

Hasil pengujian TSS diketahui dari Gambar 10, meskipun pada sampel Bak 2 (147,8 $\mathrm{mg} / \mathrm{L})$ mengalami kenaikan dari sampel Bak 1 (139,9 mg/L), grafik sampel Model Reaktor 3 Filter cenderung menurun dimulai dari sampel inlet $(189,5 \mathrm{mg} / \mathrm{L})$ hingga sampel akhir di Bak 4 (46,8 mg/L). Sedangkan pada Model Reaktor 4 Filter, terjadi fluktuasi yang cukup tinggi. Sampel Bak $1(471,3 \mathrm{mg} / \mathrm{L})$ naik signifikan dibandingkan dengan sampel inlet (189,9 mg/L). Kemudian turun pada sampel Bak 2 (285 mg/L). Lalu naik kembali pada sampel Bak 3 (387,7 mg/L). Kemudian turun lagi pada nilai terendahnya di sampel Bak 4 $(175,7 \mathrm{mg} / \mathrm{L})$. Hingga pada akhirnya kembali naik secara signifikan pada sampel Bak 5 (356,8 mg/L). Dengan nilai akhir TSS sampel Bak 4 Model Reaktor 3 Filter sebesar 46,8 $\mathrm{mg} / \mathrm{L}$, maka telah memenuhi standar baku mutu pada Peraturan Gubernur Jatim Nomor 72 Tahun 2013, namun belum memenuhi Peraturan Menteri LHK Nomor 68 Tahun 2016. Sedangkan sampel Bak 5 Model Reaktor 4 Filter belum memenuhi baku mutu yang ditetapkan pada kedua peraturan sehingga belum memenuhi standar.

\subsection{Pembahasan}

\subsubsection{Efisiensi filtrasi}

Nilai efisiensi dihitung dengan Persamaan 5. Perhitungan efisiensi dilakukan dengan membandingkan perbaikan nilai efluen suatu parameter yang dilakukan sebuah model reaktor terhadap influen.

Dari Tabel 3, dapat diketahui bahwa Model Reaktor 3 Filter menunjukkan nilai persentase yang positif, sehingga dapat memperbaiki nilai semua parameter dari influen. Sedangkan Model Reaktor 4 Filter gagal memperbaiki nilai parameter COD dan TSS. 
Tabel 3: Efisiensi rerata filtrasi model reaktor

\begin{tabular}{ccccccc}
\hline \multirow{2}{*}{ Parameter } & \multirow{2}{*}{$\begin{array}{c}\text { Influen } \\
\end{array}$} & \multicolumn{2}{c}{ Efluen Rerata $(\mathrm{mg} / \mathrm{L})$} & & \multicolumn{2}{c}{ Efisiensi Rerata $(\%)$} \\
\cline { 3 - 4 } \cline { 6 - 7 } & & 3 Filter & 4 Filter & & 3 Filter & 4 Filter \\
\hline pH & 6,5 & 7,25 & 7,5 & & 11,54 & 15,38 \\
BOD & 75,25 & 55,58 & 71,45 & & 26,15 & 5,05 \\
COD & 243,3 & 192,73 & 250,15 & & 20,79 & $-2,82$ \\
TSS & 121,85 & 65,35 & 260,75 & & 46,37 & $-113,99$ \\
\hline
\end{tabular}

\section{Kesimpulan}

Hasil analisis kualitas air pada Pengujian 1 pada hari ke-1 menunjukkan bahwa sampel Kolam Inlet memiliki nilai pH 6,4; BOD 70,2 mg/L, COD 245,6 mg/L, dan TSS 54,2 mg/L. Model Reaktor 3 Filter memiliki efluen dengan nilai pH 7,5; BOD 35 mg/L, COD 99,06 $\mathrm{mg} / \mathrm{L}$, dan TSS 83,9 mg/L. Sedangkan Model Reaktor 4 Filter memiliki efluen dengan nilai pH 7,7; BOD 65,9 mg/L, COD $210 \mathrm{mg} / \mathrm{L}$, dan TSS 164,7 mg/L. Parameter pH dapat diperbaiki oleh kedua model reaktor hingga sesuai dengan baku mutu. Namun, parameter selain $\mathrm{pH}$, yaitu COD, hanya bisa diturunkan hingga di bawa baku mutu Permen LHK melalui Model Reaktor 3 Filter.

Hasil analisis kualitas air pada Pengujian 2 pada hari ke-10 menunjukkan bahwa sampel Kolam Inlet memiliki nilai pH 6,6; BOD 80,3 mg/L, COD $241 \mathrm{mg} / \mathrm{L}$, dan TSS $189,5 \mathrm{mg} / \mathrm{L}$. Model Reaktor 3 Filter memiliki efluen dengan nilai pH 7,0; BOD 76,15 mg/L, COD 286,4 mg/L, dan TSS 46,8 mg/L. Sedangkan Model Reaktor 4 Filter memiliki efluen dengan nilai $\mathrm{pH}$ 7,3; BOD $77 \mathrm{mg} / \mathrm{L}$, COD 290,3 mg/L, dan TSS 356,8 mg/L. Parameter $\mathrm{pH}$ dapat diperbaiki oleh kedua model reaktor hingga sesuai dengan baku mutu. Namun, parameter selain $\mathrm{pH}$, yaitu TSS, hanya bisa diturunkan hingga di bawa baku mutu Pergub Jatim melalui Model Reaktor 3 Filter.

Efisiensi rerata filtrasi yang dilakukan oleh Model Reaktor 3 Filter pada parameter $\mathrm{pH}$ adalah $11,54 \%$, BOD 26,15\%, COD 20,79\%, dan TSS 46,37\%. Sedangkan efisiensi Model Reaktor 4 Filter pada pH 15,38\%, BOD 5,05\%, COD -2,82\%, dan TSS $-113,99 \%$. Model Reaktor 3 Filter menunjukkan efisiensi rerata filtrasi yang lebih baik daripada Model Reaktor 4 Filter, dengan menunjukkan nilai persentase yang positif terhadap semua parameter.

Teramati adanya anomali berupa lonjakan yang drastis pada Bak 1 di kedua model reaktor. Hal ini dimungkinkan terjadi karena proses pengambilan sampel yang tidak benar, yaitu adanya pengadukan. Untuk itu, pada penelitian lain yang serupa, sebaiknya pengambilan sampel dilakukan dengan perlahan.

\section{Daftar Pustaka}

[1] Direktorat Pengendalian Pencemaran Air KLHK, Laporan Kinerja Tahun 2018. Jakarta: Kementerian Lingkungan Hidup dan Kehutanan, 2019.

[2] E. N. Cahya, E. Arifi, and R. Haribowo, "Recycled Porous Concrete Effectiveness for Filtration Material on Wastewater Treatment," Int. J. GEOMATE, vol. 18, no. 70, pp. 209-214, 2020, doi: 10.21660/2020.70.9266. 
[3] A. R. M. P. Gunawan, E. N. Cahya, and E. Yuliani, "Pemanfaatan Beton Poros Recycle Agregat sebagai Media Filtrasi Air Limbah Domestik MCK Terpadu Kelurahan Tlogomas Kota Malang," J. Mhs. Jur. Tek. Pengair., vol. 1, no. 1, 2017, [Online]. Available:

http://pengairan.studentjournal.ub.ac.id/index.php/jmtp/article/view/6/5.

[4] O. Nkwonta, "A Comparison of Horizontal Roughing Filters and Vertical Roughing Filters in Wastewater Treatment Using Gravel as a Filter Media," Int. J. Phys. Sci., vol. 5, no. 8, pp. 1240-1247, 2010.

[5] M. M. Taghizadeh, A. Torabian, M. Borghei, and A. H. Hassani, "Feasibility Study for Water Purification using Vertical Porous Concrete Filter," Int. J. Environ. Sci. Technol., vol. 4, no. 4, pp. 505-512, 2007, doi: 10.1007/BF03325987.

[6] D. Trisnoyuwono, Beton Non-Pasir. Yogyakarta: Graha Ilmu, 2014.

[7] Mahardi and R. Ikhsan, "Sistem Perencanaan Penyaluran Air Buangan Domestik di Kecamatan Telanaipura Kota Jambi," J. Ilm. Univ. Batanghari Jambi, vol. 15, no. 2, pp. 06-12, Nov. 2010, doi: 10.33087/jiubj.v15i2.174.

[8] Badan Standardisasi Nasional, SNI 6728.1:2015 tentang Penyusunan neraca spasial sumber daya alam - Bagian 1 : Sumber daya air. Jakarta: BSN, 2015.

[9] Y. K. Tumanan, A. Binilang, and I. R. Mangangka, "Pengembangan Sistem Penyediaan Air Bersih di Desa Uuwan Kecamatan Dumoga Barat Kabupaten Bolaang Mongondow,” J. Sipil Statik, vol. 5, no. 4, pp. 225-235, 2017.

[10] BPS Kota Malang, Kota Malang Dalam Angka 2018. Kota Malang: Badan Pusat Statistik, 2019.

[11] F. Mubin, A. Binilang, and F. Halim, "Perencanaan Sistem Pengolahan Air Limbah Domestik di Kelurahan Istiqlal Kota Manado," J. Sipil Statik, vol. 4, no. 3, pp. 211-223, 2016.

[12] Badan Standardisasi Nasional, SNI 6989.59:2008 tentang Air dan Air LimbahBagian 57: Metoda Pengambilan Contoh Air Limbah. Jakarta, Republik Indonesia: BSN, 2008.

[13] Menteri Lingkungan Hidup, Peraturan Menteri Lingkungan Hidup Republik Indonesia Nomor 5 Tahun 2014 tentang Baku Mutu Air Limbah. Jakarta: Sekretariat Negara, 2014.

[14] Menteri Lingkungan Hidup dan Kehutanan, Peraturan Menteri Lingkungan Hidup dan Kehutanan Nomor 68 Tahun 2016 tentang Baku Mutu Air Limbah Domestik. Jakarta: Sekretariat Negara, 2016.

[15] Gubernur Jawa Timur, Peraturan Gubernur Jawa Timur Nomor 72 Tahun 2013 tentang Baku Mutu Air Limbah Bagi Industri dan/atau Kegiatan Usaha Lainnya. Surabaya: Sekretariat Daerah, 2013.

[16] M. N. Rhomadhoni and Sunaryo, "Efisiensi Instalasi Pengolahan Air Limbah (IPAL) dalam Menurunkan Parameter Kimia terhadap Bau di Salah Satu Rumah Sakit Swasta di Madiun," J. Ilm. Tek. Lingkung., vol. 8, no. 2, pp. 132-137, 2016, [Online]. Available: http://repository.unusa.ac.id/2724/. 